\title{
Mobile Commerce Adoption in North American Organizations: An Empirical Study of Organizational Factors
}

\author{
Srimannarayana Grandhi and Santoso Wibowo
}

CQUniversity, Melbourne, Australia

Correspondence should be addressed to: Srimannarayana Grandhi; s.grandhi@cqu.edu.au

Received date: 7 April 2015; Accepted date: 3 February 2016; Published date: 4 October 2016

Copyright (C) 2016. Srimannarayana Grandhi and Santoso Wibowo. Distributed under Creative Commons CC-BY 4.0

\begin{abstract}
Mobile commerce or M-commerce can be seen as transactions made using mobile devices such as cellular phones and other mobile devices including tablet PCs. Advancements in mobile technologies and the availability of low cost mobile devices triggered the opportunities for mobile commerce. In recent years, it has become a shopping tool for many mobile users as it allows convenience and flexibility. This research paper highlights the role of organizational factors leading to the adoption of mobile commerce. This paper utilizes publicly available data collected from both IT and non-IT professionals working in North America. This study is based on secondary data and explored the interrelationships between strategy, perception and commitment, perceived business benefits, inhibitors and interface design. The results suggest that factors such as organization's strategy, organizations' perception of m-commerce benefits, inhibitors and interface design features are the key indicators of organizations' readiness to adoptm-commerce. This study offers valuable insights to better understand mobile commerce adoption drivers and it can be helpful for organizations with similar interests.
\end{abstract}

Keywords: Mobile Commerce, North America, Adoption, Organizations' Preparedness, Influencing Factors.

\section{Introduction}

In recent years, the shift from $2 G / 2.5 G$ to $3 G$ or $4 G$ technologies has allowed for higher data transfers. In addition to these advancements, smart phones have opened up new ways to promote products and services. As a result, organizations have invested heavily in mobile shopping channels to disseminate content and promote their goods and services (Liu and Liou, 2011). Mobile commerce (m- commerce) can be viewed as electronic transactions that are conducted through the use of mobile devices such as cellular phones and other mobile devices (Jessup and Valacich, 2007) including tablet PCs. Tiwari and Buse (2007) have defined it as any transaction, involving the transfer of ownership or rights to use goods and services, which is initiated and/or completed by using mobiles' access to computer-mediated networks with the help of mobile device. 
International Telecommunication Union (ITU) figures suggest that mobile subscriptions worldwide have surpassed 6 billion in 2011 and 7 billion in 2014 (ITUa, 2014). Developing countries are leading the way in acquiring mobile phone services. The availability of mobile phone services, the cost of acquiring a device and subscription and the inaccessibility to traditional fixed line service are the major reasons for this surge in mobile subscriptions (ITUa, 2014). On top of that, developed countries are found to be ahead in using 3G and 4G technologies which allow higher data transfer rates. Higher data transfer rates are important for downloading data and video rich content to mobile phones. These new technologies clearly present new opportunities to businesses in those countries as customers are positive about adopting new technologies. In fact, GSMA predicts that about $53 \%$ of total mobile subscriptions will use either 3G or 4G networks by 2017 to access data through their mobile devices. Data access needs are mostly driven by the increased penetration of smart phones and tablet PCs that allows users to download data-hungry applications through $3 \mathrm{G}$ or $4 \mathrm{G}$ networks (GSMA, 2013). Gartner's predictions in 2010 suggested that the majority of mobile devices allow users to browse the Internet and install applications to enhance user experience (Gartner, 2010).

Statistics have also shown that even though fixed telephone line subscriptions have dropped from 48 to $41 \%$ in these countries, they are ahead in terms of having access to internet. Another interesting fact is that there are 84 mobilebroadband subscriptions per every 100 inhabitants by early 2014 (ITUb, 2014). These figures clearly outline opportunities for businesses in developed countries and prompt the need to develop mobile interface, participate in m-commerce and promote their products and services.

M-commerce provides flexible accessibility by allowing users to access the same content that can be accessed through personal computer (Jessup and Valacich, 2007). As mobile devices can be carried anywhere, they provides access to the
Internet indefinitely as long as there is a service offered by mobile service provider, Internet Wi-Fi service provided locally or by another mobile device through tethering option (Valacich and Schneider, 2014). Uninterrupted Internet access facilitates users to carry out online transactions without the need to use desktop computers. Recent advancements such as Near Field Communication (NFC) allows users to store their credit card details and make payments using their mobile wallet saving from the need to carry several cards such as credit card, membership cards, and loyalty cards (Woodward, 2011).

The introduction of m-commerce is attracting a lot of attention from organizations to promote and sell their products and services online. Therefore, we trust that a clear understanding of the influencing factors mentioned in this paper can help organizations predict their preparedness for adopting m-commerce. This research utilizes publicly available data collected from 1182 IT and non-IT professionals working in the North American region.

In what follows, we first present a literature review on the use of mcommerce around the world including North America and relevant models that help predict organizations' m-commerce preparedness in Section II. We then present our hypotheses in Section III with supporting evidence. The methodology is presented in Section IV, followed by the discussion in Section V. The conclusion, research implications, and limitations of the research are provided in Section VI.

\section{Literature Review}

\section{M-commerce}

Valacich and Schneider (2014) have defined m-commerce as the means of conducting transaction through the use of mobile devices over wireless networks. Tiwari and Buse (2007) have defined mcommerce as any type of transactions involving transfer of goods and services through the use of mobile devices. Interestingly, researchers considered m- 
commerce as the subset of broader ecommerce because of the way transactions are conducted through mobile devices which simulate the desktop environment and allows users to complete several transactions (Valacich and Schneider, 2014). In recent years, there is an explosive growth in the use of mobile devices, such as mobile phones and tablet PCs with the Internet browsing capability. Therefore, Feng et al. (2006) argued that m-commerce can be considered an extension of ecommerce as it has the ability to offer a new business model with different usage patterns and interaction styles. Mcommerce business model offers mobility and reachability as mobile devices can be carried easily and can be connected to the Internet through mobile service providers (Haque, 2004; Li and Yeh, 2010; Liu and Liou, 2011). Interestingly, most of the studies related to $\mathrm{m}$-commerce adoption are focused on consumers' intention to adopt new technology, and there is a lack of research in identifying what factors influence organizations to adopt mcommerce. According to Schwalbe (2014) adoption of new technology is dependent on organization's commitment to allocate sufficient budgets and continuous support to the project team. Identifying the possible factors and their influence on business outcomes can help organizations commit on the m-commerce adoption. Therefore, this paper attempts to identify critical success factors that can help predict organizations' preparedness to adopt mcommerce.

\section{M-commerce in North America and around the world}

Ericsson's mobility report stated that by early 2014, there were about 6.8 billion mobile subscriptions around the world, which is 120 million more compared to the previous quarter. During the same time, the global mobile penetration reached 93 percent, and interestingly, $35 \%$ are associated with smart phones. This report also revealed that developing countries in Asia particularly India, China, Indonesia, Thailand and Bangladesh are the major contributors to this explosive growth. Ericsson's report predicts that worldwide mobile subscriptions will reach 9.2 billion by the end of 2019 (Ericsson, 2014). Asia pacific region leads the way in terms of both connections and subscribers, representing just below $50 \%$ of the total connections (GSMA, 2013).

According to Forrester research, mobile payments have reached more than US $\$ 12.8$ billion and are expected to grow by about $600 \%$ by the end of 2017 (Siwicki, 2013). However, factors such as mobile device cost, affordability, service availability, local government regulations and service providers' preparedness to offer value added services may influence individuals' intention to acquire mobile subscription and use mobile based services. Falling prices, availability of disposable income, lack of economically viable alternatives and availability of new technologies with significant infrastructure are the major drivers for growth in mobile subscription rates. However, the nature of growth is different in developed markets such as in North America and Europe (GSMA, 2013).

It is predicted that North America will top the list of NFC usage by 2016. NFC allows mobile devices to exchange data allowing consumers to make payments by waving a smartphone with a NFC-enabled device (Woodward, 2011). A survey of more than 100 retailers indicates that e-commerce powerhouses such as Amazon and eBay are using mobile phones as a way to provide convenience and brand loyalty. It is also revealed that $20 \%$ of respondents believe that mobile transactions have increased from 16 to 20\% in 2012 (Ross, 2013). Adyen, a multi-channel payment solutions provider revealed that there was $27 \%$ growth worldwide in mobile transactions mobile payments in 2013, while mobile payments in North American region have surged to $16.6 \%$ during the same time. The majority of mobile payments were to purchase travel related products including airfares, retail, ticketing, gaming and other digital goods (Adyen, 2013). 


\section{Factor influencing the adoption of $\mathrm{m}$ - commerce}

M-commerce is considered an extension or a subset of e-commerce (Tiwari and Buse, 2007). Initially, there may be a small group of "innovators", who would be willing to adopt new technologies. Usually early adaptors are the ones who may gain competitive advantage, whereas laggards lose out the benefits and the competitive advantage early adaptors enjoyed (Valacich and Schneider, 2014).

Mobile technologies are proven to be an important tool for organizations to market their products and services and establish communication with their customers (Haque, 2004). Formulation of mcommerce strategies can help organizations benefit from these new technologies (Thompson et al., 2010). Similarly, organizations' perception and commitment (Carr, 2003), perceived business benefits can generate interest among businesses about mobile technologies and influence the adoption of mobile technologies (Lee, 2009), however understanding of $\mathrm{m}$-commerce inhibitors and features (Wei and Ozok, 2005) offered by these technologies can help justify the need for mobile technologies.

Consumers' preparedness to accept new technologies can be a strong indicator for $\mathrm{m}$-commerce adoption by organizations (Bruner and Kumar, 2003). In order to gain an understanding of the factors affecting m-commerce adoption, several models including Theory of Reasoned Action (TRA) Technology Acceptance model (TAM), Diffusion of Innovation model (DOI), Unified Theory of Acceptance and use of Technology (UTAUT) and Motivational Model are examined (Lala, 2014). Although there are several models, research suggests that TAM and DOI are the most common models used to determine the possibilities of m-commerce adoption, e-commerce, Internet banking, online shopping and online learning (Ashraf et al., 2014; Sulistiyaningsih et al., 2014). Also, mcommerce is considered a subset or an extension of e-commerce and has several similar characteristics. Hence, TAM and
DOI can be used to predict organizations' preparedness to adopt m-commerce.

TAM model is based on information systems theory and suggests that when customers are offered with new technology, then factors such as when to use and how to use can influence their intention to use that technology. In fact, consumers' motivation to adopt new technology can be understood through factors such as perceived ease of use, perceived usefulness and their attitude (Lala, 2014). Davis (1986) suggested that perceived ease of use can lead to behavioral modification to adopt new technology and use. Therefore, the growth in the use of mobile devices for online activities can be perceived as an opportunity for organizations to modify their behavior and subsequently adopt mcommerce.

Diffusion of Innovation (DOI) theory can be helpful in understanding the key factors that can predict organizations' preparedness to adopt new technologies such as m-commerce. DOI helps to understand the conditions that will have an impact on adopting a new product, ideas or practices in a specific culture. Research done by Ball et al. (2014) stated the reasons why consumers tend to adopt new ideas. Rogers (1995) explained that innovation occurs trough four stages namely (a) invention, (b) diffusion, (c) time and (d) consequences.

According to Rogers (2003), innovation can be through a new idea, a practice or a product. Diffusion can be explained as a process of communicating innovation through specific channels. Through unique characteristics, mobile technologies can create value through chain of activities in operations, procurement, marketing and sales (Picoto et al., 2013). DOI lays out steps for innovation and adoption of new technologies, which can be used for mcommerce. DOI is a multi-stage approach allows organizations to analyze adoption process thoroughly and gain insights into the problems that may arise when technology diffusion takes place (Rogers, 2003). Sometimes, organizations will have 
no option except investing in new technologies to gain competitive advantage. According to Valacich and Schneider (2014), strategic necessities can be best utilized if there is a proper business/IT alignment. In fact, organizations' understanding and perception about the possible benefits with new technologies such as m-commerce can influence their preparedness to adopt new technologies (Lee, 2009). After all, assessing the value of new technologies and development of business models are based on the assessment of business needs and demands from the users (Valacich and Schneider, 2014). Due to these reasons, TAM and DOI models are used to study critical factors that can help predict organizations' preparedness to adopt mcommerce.

\section{Hypotheses and Research Model}

\section{Strategy}

Strategy refers to plans developed by the organization to achieve their long term goals. Organizations' vision and mission are the key indicators of their direction, while organizational strategy helps to achieve goals. Therefore, strategy formulation can be viewed as an important step towards achieving goals as it can guide the organization throughout the process (Thompson et al., 2010). The development of an m-commerce strategy usually involves several steps including (a) identifying champions, (b) preparing the organization to commit by clarifying on how m-commerce can support in carrying out core activities, (c) linking technology, (d) aligning mobile strategy to overall strategy, (e) setting realistic timelines, (f) market and integrate loyalty, and (g) capitalize on investments (Khan, 2012).

Research done by Swilley (2012) suggested that organizations are more likely to have m-commerce strategies in a competitive environment and may not show interest in adopting it, if it is solely used to improve relations with customers. Regardless of the reasons, m-commerce allows businesses to offer their products and services conveniently, improve response times and service quality through effective communication (Bang et al., 2013). Although, it would be difficult to measure intangible benefits of m-commerce such as service quality and satisfaction level, they will influence customers decision to continue or return in future. The Internet has proven to be a very important resource, not only for searching but also for buying and selling goods and services (Valacich and Schneider, 2014). Traditionally, communication strategies are based on interruption logic, where customers are not given the choice. In fact, customers' attitudes, interests and their buying behavior can be different from organizations' strategy. Mobile technologies facilitate direct and interactive marketing and allow two way communications to offer products and services based on their interest. As mcommerce offers unlimited possibilities, adopting $\mathrm{m}$-commerce strategy will help organizations to benefit from increased ecommerce activities (Haque, 2004). Therefore, we attempt to understand the preparedness of North American organizations in adopting $\mathrm{m}$-commerce strategy.

H1: The development of an m-commerce strategy will be positively associated with the organization's intention to adopt mcommerce.

\section{Commitment}

Commitment can be the strength of responsibility feeling towards their goals. It plays an important role in adopting mcommerce. Several organizations in the past have adopted $\mathrm{m}$-commerce technology because their competitors had something similar. In reality, this attitude would not provide long term benefits as it may lack commitment from the organization (Carr, 2003). Organizations' perception about possible benefits and risks determines their preparedness to adopt new technologies. Perception about the use of m-commerce can influence management's attitude and behavior (Lee, 2009). Carr (2003) suggested that technology would provide competitive advantage in the early stage, but it would not offer any advantage 
when competitors have adopted similar technology. Therefore, mobile strategy needs to be developed after careful assessment of the needs and possible benefits.

Organizations' commitment can be realized through the support offered by the top management. Senior management plays vital role and their strategic decisions influence how their goals can be achieved (Hitt et al., 2013). Zwikael (2008) listed top management support processes which include allowing project manager's involvement from initiation stage, and supporting project team by providing required resources. The implementation of a mobile strategy involves purchasing of software, hardware and acquiring other resources, which involve huge investments. Senior management support is considered vital (Michela et al., 2012) as it authorizes changes and ensures budget allocations.

Without proper resource allocations in the budget, it would prove impractical to implement m-commerce strategy. Sometimes when resources are limited, innovative mobile execution strategies such as shifting resources from low-valueadding activities to high-priority activities can help (Thompson et al., 2010). Top management support is vital for any project as organizational issues are perceived to be given more importance compared to technical issues (Zwikael, 2008). Research also revealed that when employees perceived that they have support from the organization, they would tend to show higher levels of organizational citizenship behavior (Robbins et al., 2011) which can lead to a successful project implementation. As organizations' commitment can ensure successful implementation of $\mathrm{m}$-commerce strategy, allocation of sufficient funds in the budget and promoting products through mobile based applications and increasing sales through $\mathrm{m}$-commerce can support faster implementation.

H2: Organizations' commitment to adopt m-commerce can be observed through management's actions in formulating budgets and relevant strategies.

\section{Perceived Business Benefits}

It is the organisation's perception about the positive outcomes that may be the consequence of changes (Leung, 2013) achieved through the enforcement of new technology. Mobile technologies have unique characteristics namely portability, user identification, localization and instant connectivity. These characteristics provide value and support businesses in internal operations, procurement, marketing and sales (Picoto et al., 2013). Although mobile channel does not guarantee any specific benefits instantly, growth of mobile subscription and use of smart phones often create opportunities for businesses to promote their products and services. Organizations' preparedness to adopt new technologies is perception dependant, which then influences management's attitude and behavior (Lee, 2009). As a result, it may lean towards adopting mcommerce strategy. Research also revealed that perceived benefits have influence over attitudes towards using m-commerce as a strategy (Khan, 2012).

Some of the perceived benefits of $\mathrm{m}$ commerce include its ability to allow businesses to reach new customers in different geographic regions through relevant mobile network service providers (Picoto et al., 2013). As these customers are connected to one of the mobile cell towers, it is easy to identify their exact location and offer location-specific solutions. Search engines, such as Google identifies the user's location and present location specific search results to the users (Google, 2014). This approach opens up new opportunities for businesses to promote relevant products and services in a timely manner through search engines or offer these directly through mobile network service providers.

Some of the value-added services offered to customers include real-time comparison of different products in terms of cost and features. Mobile cell towers maintain constant communication with mobile phones registered in that area and these statistics can be used to identify facts such as customers' precise location and their 
interests (Picoto, 2011). In fact, organizations can find out about the number of customers situated in a specific location and their search behavior for promoting their products and services to that geographically separated group in the form of 'flash sales'. UK online wine retailer Vente-privee.com has adopted this approach to improve wine sales on their website (McKenna, 2014). This approach is also proven to be very popular with supermarkets, where customers are offered spot discounts during lunch time or at a specific time to promote sales. As loyalty programs drive up company sales (Evanschitzky et al., 2012), returning customers can be offered special discounts and issued with electronic vouchers to provide flexibility for their purchases. If the organization has clear understanding of $\mathrm{m}$ commerce use in their environment and knew how to use it, then it would lean towards adopting it. Therefore, we hypothesize that organizations' understanding/perception is a key driver towards m-commerce adoption.

H3: Perception of business benefits positively influences Organizations' intention to adopt m-commerce.

\section{Inhibitors}

Inhibitors are the factors which influence organizations' decisions negatively (King, Grover \& Hufnagel, 1989). Some of the inhibitors of m-commerce are (a) compliance concerns, (b) lack of direction, (c) poor knowledge of financial implications including return on investments, (d) consumer perception that $\mathrm{m}$-commerce is immature and therefore it is difficult to use for mobile payments, (e) lack of security standards, (f) unclear mcommerce business models and (g) lack of mobile network in certain areas (Rysavy, 2013).

Regulatory standards are introduced by both state and federal governments in each country (Newman, 2011). Compliance concerns can be seen as an inhibitor, because organizations may feel that it would be beyond their reach and difficult to meet both local state and federal regulatory standards that apply to $\mathrm{m}$ commerce. For example, organizations in North America are required to obey laws including the ones enforced by Federal Trade Commission (FTC, 2000). Jessup and Valacich (2007) explained that business models indicate how an organization would promote its products and services, offer value added services, target customers and generate revenue. These models also reveal their preparedness, strengths and strategies to achieve their goals. Adopting new business model would require reengineering of current processes (Thompson et al., 2010). Researchers also pointed out that it would be necessary to undergo business process reengineering prior to adopting new technologies as it can facilitate alignment between corporate capabilities and market opportunities that can help achieve growth (Michela et al., 2012). The introduction of new technologies can assist organizations to improve its capabilities. However, employees may resist new technology due to fear of job losses. Involving relevant stakeholders including employees can also help to minimize resistance (Valacich and Schneider, 2014).

Consumer perception about the use of mcommerce certainly influences their decision to use (Picoto et al., 2013). Design aesthetics may also lead to customer loyalty and builds trust (Cyr et al., 2006; Li and Yeh, 2010). While interface design plays an important role, policies relating to privacy and security can help customers to understand their rights. IDC report on mobile trends revealed that there are several technologies to develop a mobile platform, but it is important to develop a platform that can be used by a range of mobile devices with different mobile operating systems (IDC, 2013). In addition to these, it is mandatory to make financial assessment of future projects as this knowledge can assist in predicting financial implications and avoiding undesirable consequences. Technical feasibility is another study that can be used by organizations to identify the possibilities to use existing infrastructure (Schwalbe, 2014). Without addressing the challenges, it would be difficult to proceed with 
adopting m-commerce strategy as it may not guarantee positive outcomes.

H4: Inhibitors tend to slowdown mcommerce adoption.

\section{Features}

Features refer to distinctive characteristics or attributes or m-commerce sites. It is important for organizations to determine what contents need to be displayed on their homepage as they will lead to their competitive advantages. Al-Khalifa (2013) suggested that a good interface with navigation, relevant content and technical aspects are quality determinants of mobile websites. In fact, the user-friendly environment can accelerate the adoption of m-commerce (Wei and Ozok, 2005). While site search option and images allow users to search for a specific product and differentiate it from other products (Nielsen and Tahir, 2002), presenting other features such as customer reviews and stock levels in different stores would be helpful in purchase decisions (Valacich and Schneider, 2014). Perceived usefulness and ease of use will influence consumers' decision to engage in $\mathrm{m}$-commerce activities (Moshkovich, 2013). Other features such as shopping cart, online support through click-to-call, store locator, choice to make comparisons between products features and price and gift registry can influence customers' intention to return. Special offers and loyalty bonus can also improve customer retention rates and help reduce customer turnover (Peng et al., 2013). In addition to these, value added services such as mobile wallet which is a downloadable application that can be used to make payments can actually add flexibility and convenience to customers. NFC allows the installation of credit card chip or details on to a mobile device, which can be waved at the check-out readers to make payments, which in turn may encourage customers to participate in mcommerce activities (Moshkovich, 2013). Research also suggests that design aesthetics lead to loyalty in m-commerce as the success of $\mathrm{m}$-commerce is dependent on consumer acceptance (Cyr et al., 2006). In fact, design aesthetics act as a tool for developing trust and gaining customer attention (Li and Yeh, 2010).

H5: Mobile interface with specific features can improve customer experience and encourage their participation in mcommerce activities.

\section{Methodology}

\section{Sample and procedure}

Literature review forms the basis for this research model. The conceptual model in Fig. 1 below shows the key factors including (a) strategy, (b) organization's commitment, (c) perceived business benefits, (d) inhibitors and (e) features that may influence the organizations readiness to adopt $\mathrm{m}$-commerce. 


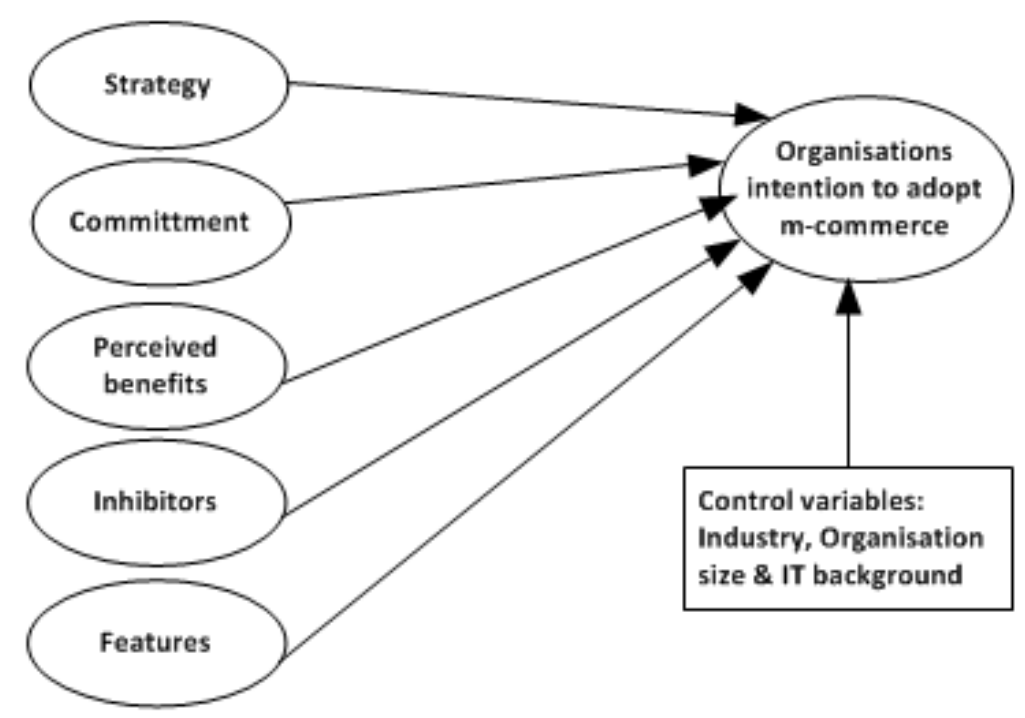

Figure 1: M-commerce influencing factors

This research utilizes publicly available secondary data that were initially collected and published online by InformationWeek under the survey name "InformationWeek and Mobile Commerce World Commerce Survey". Upon receiving an email invitation, this online survey was completed by 1182 qualified
InformationWeek, Bank Systems and Technology and Light Reading subscribers. About 76\% (895 of 1182) respondents are either familiar or involved with their organizations' m-commerce strategies. More detailed demographics are presented in Table 1 below.

Table 1: Demographic Profile

\begin{tabular}{|l|l|c|}
\hline Demographic profile & Number & $\mathbf{\%}$ \\
\hline Banking and payments and telecom/ISPs & 568 & 48 \\
\hline IT director/manager or IT executive management level & 413 & 35 \\
\hline Non-IT executives or line of business management & 201 & 17 \\
\hline Organization size (5000-10000) & 425 & 36 \\
\hline Organization size $>10000$ & 343 & 29 \\
\hline Staff involved with organizations mobile strategy & 895 & 76 \\
\hline
\end{tabular}

\section{Variable measurement}

Consistent with previous technology adoption studies, the independent and dependent variables used in this study are derived from the existing literature (Wei et al., 2009). 14 items were used to measure 5 independent variables in this study, and 5 questions were used to measure the dependent variables. Besides the demographic profiles, all items were measured on a 5 point Likert Scale ranging 
from 1 (strongly disagree) to 5 (strongly agree).

Scale reliability and factor analysis
The reliability of the questionnaire was tested using Cronbach's alpha. The reliability coefficients $(\alpha)$ for the data set are shown in Table 2.

Table 2 : Reliability Analysis

\begin{tabular}{|l|c|}
\hline Variables & Cronbach's alpha \\
\hline Strategy & 0.913 \\
\hline Commitment & 0.894 \\
\hline Perceived business benefits & 0.873 \\
\hline Inhibitors & 0.841 \\
\hline Features & 0.826 \\
\hline
\end{tabular}

Table 3 : Factor Analysis

\begin{tabular}{|l|c|c|c|c|}
\hline \multicolumn{1}{|c|}{ Constructs } & $\begin{array}{c}\text { Number of } \\
\text { items }\end{array}$ & $\begin{array}{c}\text { Factor } \\
\text { loadings }\end{array}$ & Eigenvalues & Variance \% \\
\hline Strategy & 4 & $0.71-0.78$ & 2.84 & 10.14 \\
\hline Commitment & 4 & $0.66-0.80$ & 1.58 & 5.67 \\
\hline $\begin{array}{l}\text { Perceived } \\
\text { business benefits }\end{array}$ & 3 & $0.83-0.84$ & 1.36 & 4.85 \\
\hline Inhibitors & 3 & $0.79-0.86$ & 1.35 & 4.81 \\
\hline Features & 3 & $0.67-0.84$ & 1.11 & 3.96 \\
\hline
\end{tabular}

The reliability coefficients $(\alpha)$ of all independent variables are above 0.70 , thus confirming that the items used to measure the constructs are reliable (Hair et al., 2006). In order to test the validity of the constructs, factor analysis is applied. The model consists of variables that are catered towards m-commerce adoption. Furthermore, some of the items adapted were not studied in North America. Therefore, exploratory factor analysis is applied instead of confirmatory factor analysis (Chong and Ooi, 2008). Principal component analysis is chosen to evaluate if the items are linked to their underlying factors. Table 3 shows the results.
Factor loading of 0.50 was used as a cut-off point as suggested by Hair et al. (2006). Factors which have eigenvalues of less than one are considered insignificant and are therefore disregarded (Chong and Ooi, 2008). Based on Table 3 , all items have a factor loading of more than 0.50 , thus confirming that these constructs are unidimensional and factorially distinct, and the items used to operationalize the constructs are all loaded onto a single factor (Teo, 2001).

\section{Intercorrelation matrix}

This section presents an intercorrelation matrix for the demographic profiles of the 
organizations and the m-commerce activities. Based on Table 4, it is shown that size of the organization and service-related type of industry are positively correlated $(\mathrm{r}=0.25)$. This implies that larger organizations in the samples tend to be more prepared for adopting $\mathrm{m}$-commerce. The results show that service-related industries tend to adopt m-commerce based on strategy $(\mathrm{r}=0.12)$ and perceived business benefits $(r=0.16)$. In terms of the size of the organizations, large organizations feel that strategy $(r=0.13)$ and perceived business benefits ( $r=0.21$ ) are important aspects in m-commerce adoption.

Table 4: Intercorrelation Matrix

\begin{tabular}{|l|l|l|l|l|l|l|l|}
\hline Variables & $\mathbf{1}$ & $\mathbf{2}$ & $\mathbf{3}$ & $\mathbf{4}$ & $\mathbf{5}$ & $\mathbf{6}$ & $\mathbf{7}$ \\
\hline $\begin{array}{l}\text { Size of the } \\
\text { organization }\end{array}$ & 1 & 0.25 & 0.13 & -0.08 & 0.21 & 0.17 & -0.02 \\
\hline $\begin{array}{l}\text { Service-related } \\
\text { industry }\end{array}$ & 0.25 & 1 & 0.12 & 0.03 & 0.16 & 0.11 & 0.04 \\
\hline Strategy & 0.13 & 0.12 & 1 & 0.19 & 0.05 & 0.03 & 0.05 \\
\hline Commitment & -0.08 & 0.03 & 0.19 & 1 & 0.14 & 0.12 & 0.17 \\
\hline $\begin{array}{l}\text { Perceived } \\
\text { business benefits }\end{array}$ & 0.21 & 0.16 & 0.05 & 0.21 & 1 & 0.28 & 0.04 \\
\hline Inhibitors & 0.17 & 0.11 & 0.03 & 0.12 & 0.28 & 1 & 0.16 \\
\hline Features & -0.02 & 0.04 & 0.15 & 0.17 & 0.04 & 0.16 & 1 \\
\hline
\end{tabular}

\section{Hypotheses testing}

To test the research hypotheses, hierarchical regression analysis was used. The method is suitable as it allows the examination of the effects of the control variables and the independent variables separately. Multicollinearity of data was tested using VIF and Tolerance. All the independent variables have VIF values of less than 10, and Tolerance values of more than 0.10 , thus ensuring that the data did not suffer from multicollinearity. The dependent variable also has skewness and kurtosis values between -1.0 and +1.0 , thus ensuring that the data used in the study are normally distributed.

In step 1 of the hierarchical regression analysis, demographic variables were entered to examine their effects on the organizations' preparedness to adopt mcommerce. In step 2, the adoption factors are entered and allow the examination of any increase in explained variance over that contributed by the demographic variables (Teo, 2001). The results are shown in Table 5.

Based on Table 5, demographic profiles only contributed $16 \%$ towards the North American organizations' preparedness to adopt m-commerce. In contrast, the adoption factors in this study are able to predict $32 \%$ of North American mcommerce adoption decisions. 
Table 5 Hierarchical Regression Analysis

\begin{tabular}{|l|l|l|}
\hline Research variables & Step 1 & Step 2 \\
\hline Size of the organization & 0.18 & 0.04 \\
\hline Service-related industry & 0.14 & 0.27 \\
\hline Strategy & & 0.34 \\
\hline Commitment & & -0.16 \\
\hline Perceived business benefits & & 0.16 \\
\hline Inhibitors & & 0.26 \\
\hline Features & & 0.13 \\
\hline Adjusted R & & 0.32 \\
\hline
\end{tabular}

Strategy, perceived business benefits, inhibitors and features of m-commerce are able to significantly predict the adoption decision of m-commerce in North American organizations. Therefore $\mathrm{H} 1, \mathrm{H} 3, \mathrm{H} 4$ and H5 are supported. Perception and commitment has no significant relationship with the organizations' decision to adopt $\mathrm{m}$-commerce, thus $\mathrm{H} 2$ is rejected.

\section{Discussion}

Summary of major findings are presented in this section to provide clarity on factors for determining North American organizations' preparedness to adopt mcommerce in the near future. Almost all of the results obtained in the previous section supported established hypotheses except one. Results revealed that organizations' size to some extent can be a good predictor about their preparedness. Interestingly, organizations' perception and commitment has no relationship to their interest in adopting m-commerce. Schwalbe (2014) suggests that organizations' perception about the future benefits plays a role in choosing project. However, the results contradict with the view of Hitt et al (2013) and Zwikael (2008). It may be because organizations tend to select projects that meet current priorities and often provide measurable outcomes (Schwalbe, 2014).
Strategy is found to be the most significant predictor of $\mathrm{m}$-commerce adoption by organizations, as strategy is developed after careful analysis of both internal and external environments including strengths, weaknesses, opportunities and threats (Thompson et al., 2010). Results are consistent with the literature and suggest that organizations' strategy can hint their preparedness to adopt $\mathrm{m}$-commerce, but it does not indicate their commitment level or implementation timelines. Based on the TAM model, usefulness and perceived ease of use are the two influencing factors for deciding whether to use the technology (Davis, 1986; Mahatanankoon and VilaRuiz, 2007). The results also support that customers' perception about the mcommerce benefits will influence organizations' intention to adopt mcommerce. Mobile device users in North America are ahead of others in using new technologies such as NFC to make payments through mobile devices (Adyen, 2013). In fact their increased participation in $\mathrm{m}$-commerce certainly offers new hopes to organizations that are willing to adopt $\mathrm{m}$-commerce.

It is believed that inhibitors such as lack of direction and knowledge of financial implications, m-commerce business models, mature technologies and infrastructure, and security and other 
compliance concerns can slowdown mcommerce adoption. Findings also suggest the relevance between these inhibitors and organizations' preparedness to adopt mcommerce strategy. Easily navigable mobile interface allows users to complete online transactions with little effort. As there are different mobile operating systems, it is important for organizations to adopt an interface that can work the same regardless of the operating system. In addition to this, adopting standard features such as search option, store locator and online chat can encourage customer participation (Peng et al., 2013). Research also suggests that design aesthetics can lead to loyalty in m-commerce (Cyr et al., 2006) as they include value-added services such as NFC that can offer more flexibility to customers.

\section{Conclusion, Implications and Limitations}

Based on research findings, we offer specific conclusions and suggestions for the adoption of m-commerce to reach more customers and improve their profits through sales. Firstly, as strategies are developed after rigorous analysis of both internal and external environmental factors, the adoption of m-commerce strategy clearly indicates their preparedness. Secondly, organizations' perception and their commitment predict their preparedness, but organizations may tend to choose projects that may deliver measurable outcomes. However, these variables can generate interest leading to feasibility study, ultimately resulting in the adoption of $\mathrm{m}$-commerce.

Thirdly, organizations' perception about the possible benefits can have significant impact on organizations' decision to adopt m-commerce. However, users' perception may also influence the organization's preparedness to adopt m-commerce because users may be able to avail these services from others, if not offered by their current provider. Developing and adopting cross-platform interface with standard features, product or service images and information along with terms, conditions and policies can improve transparency and develop trust, which can influence individuals to purchase and promote by word of mouth, online blogs and social networking websites. Finally, we found out that organizations need to pay special attention to understanding the inhibitors for m-commerce adoption in their organizations as they can slow down the adoption process.

This study offers several implications. There is a significant increase in use of smart phones and other mobile devices because of increased affordability and new technologies. This research investigated the factors that can help predict the adoption of m-commerce by North American organizations. The results suggest that the factors such as strategy, perception and commitment, perceived business benefits, inhibitors and features of m-commerce have a significant relationship with decisions to adopt mcommerce. The results also suggest that organizations' strategy, their customers' perception about the use of m-commerce, inhibitors and interface design features have significant influence on organizations' preparedness to join m-commerce.

This study is based on secondary data and the development of a model that can be used to predict organizations' preparedness to adopt m-commerce by studying and exploring the interrelationships between strategy, perception and commitment, perceived business benefits, inhibitors and interface design. Based on these results, several suggestions are made to support the organizations' preparedness in adopting mcommerce. Despite its contributions, this study is not free from limitations. One limitation is its research setting, which was restricted to only predicting $\mathrm{m}$-commerce adoption for North American organizations. Thus, the empirical findings should be interpreted as primarily applicable to organizations in North America. Future research could extend the current study to m-commerce adoption around the world to improve the external validity and to examine the differences across heterogeneous social and cultural segments. Another limitation is that this 
study examines few of several important factors. Future studies can consider measuring the diffusion of $\mathrm{m}$-commerce across time, and investigate if the adoption factors change at various stages of consumer diffusion of $\mathrm{m}$-commerce.

\section{References}

1. Adyen (2013), Adyen reports 27 percent worldwide growth in mobile transactions over past four months. [Online], [Retrieved August 20, 2014], https://www.adyen.com/home/aboutadyen/press-room/pressreleases/2013/mobile-payments-indexseptember-2013.html.

2. Al-Khalifa, H.S. (2013), A framework for evaluating university mobile websites. Online Inform. Rev. 38, 166-185.

3. Ashraf, A., Thongapapanl, N. and Auh, S. (2014). "The application of the technology acceptance model under different cultural contexts: The case of online shopping adoption,' Journal of International Marketing, vol. 22, pages 6893.

4. Ball, J., Ogletree, R., Asunda, P., Miller, K. and Jurkowski, E. (2014). 'Diffusion of innovation elements that influence the adoption and diffusion of distance education in health,' American Journal of Health Studies, vol. 29, pages 240-247.

5. Bang, Y., Lee, D., Han, K., Hwang, M. and Ahn, J. (2013). 'Channel capabilities, product characteristics, and the impacts of mobile channel introduction,' Journal of Management Information Systems, vol. 30, pages 101-125.

6. Bruner, G. and Kumar, A. (2003). 'Explaining consumer acceptance of handheld Internet devices,' Journal of Business Research, vol. 58, pages 115-120.

7. Carr, N.G. (2003). 'IT doesn't matter,' Harvard Business Review, vol. 81, 41-49.

8. Chong, A.Y.L. and Ooi, K.B. (2008). 'Adoption of interorganizational system standards in supply chains: an empirical analysis of RosettaNet standards,' Industrial Management \& Data Systems, vol. 108 , pages $529-547$.

9. Cyr, D., Head, M. and Ivanov, A. (2006). 'Design aesthetics leading to m-loyalty in mobile commerce,' Journal of Information Management, vol. 43, pages 950-963.

10. Davis, F. (1986). A technology acceptance model for empirically testing new end-user information systems: theory and results, Doctoral Dissertation, Sloan School of Management, Massachusetts Institute of Technology.

11. Ericsson, (2014). "Ericsson Mobility Report: On the pulse of the networked society," [Online], [Retrieved April 23, 2015],

http://www.ericsson.com/res/docs/2014/ ericsson-mobility-report-june-2014.pdf.

12. Evanschitzky, H., Ramaseshan, B., Woisetschlager, D.M., Richelsen, V., Blut, M. and Backhaus, C. (2012). 'Consequences of customer loyalty to the loyalty program and to the company,' Journal of the Academy of Market Sciences, vol. 40, pages 625-638.

13. Feng, H., Hoegler, T. and Stucky, W. (2006). 'Exploring the critical success factors for mobile commerce,' International Conference on Mobile Business, Copenhagen, Denmark.

14. FTC, (2000). "Advertising and marketing on the Internet: Rules of the road," [Online], [Retrieved April 23, 2015], http://www.business.ftc.gov/documents/b us28-advertising-and-marketing-internetrules-road.

15. Gartner, (2010). "Gartner outlines 10 mobile technologies to watch in 2010 and 2011," [Online], [Retrieved April 23, 2015], http://www.gartner.com/newsroom/id/1 328113.

16. Google, (2014). "All tips \& tricks," [Online], [Retrieved April 23, 2015], http://www.google.com.au/intl/en_uk/insi desearch/tipstricks/all.html. 
17. GSMA, (2013). "The mobile economy 2013," ," [Online], [Retrieved April 23, 2015],

http://www.gsmamobileeconomy.com/GS MA\%20Mobile\%20Economy\%202013.pdf.

18. Hair, J., Black, W., Babin, B., Anderson, R. and Tatham, R. (2006) Multivariate Data Analysis, Prentice Hall, New Jersey.

19. Haque, A. (2004). 'Mobile commerce: Customer perception and its prospect on business operation in Malaysia,' Journal of American Academy of Business, vol. 4, pages 257-262.

20. Hitt, M.A., Ireland, R.D. and Hoskisson, R.E. (2013) Strategic Management Competitiveness and Globalization: Concepts and Cases, tenth ed., Cengage Learning, USA.

21. IDC, (2013). "Mobile trends report," [Online], [Retrieved April 23, 2015], http://www.appcelerator.com.s3.amazona ws.com/pdf/q4-2013-devsurvey.pdf.

22. ITUa, (2014). "The world of ICTs," [Online], [Retrieved April 23, 2015], http://www.itu.int/en/ITU-

D/Statistics/Pages/stat/default.aspx?utm_ source=twitterfeed\&utm_medium=twitter. co.jp.

23. ITUb, (2014). "ITU releases latest global technology development figures," [Online], [Retrieved April 23, 2015], http://www.itu.int/net/pressoffice/press_ releases/2012/70.aspx\#.U82-G2f9zfg.

24. Jessup, L. and Valacich, J. (2007) Information Systems Today: Managing in the Digital World, Pearson Education Inc., New Jersey.

25. Khan, W. (2012). 'Mobile payments strategy,' Journal of Payments Strategy \& Systems, vol. 6, pages 210-218.

26. Lala, G. (2014). 'The emergence and development of the Technology Acceptance Model (TAM),' International Conference on Marketing, Vol. 7, pages 149-160.
27. Lee, M. (2009). 'Factors influencing the adoption of internet banking: An integration of TAM and TPB with perceived risk and perceived benefit,' Electronic Commerce Research and Applications, vol. 8, pages 130-141.

28. Leung, Y. (2013). Perceived Benefits, In (eds.) Gellman, M.D. and Turner, J.R., Encyclopedia of Behavioral Medicine, Springer Science+Business Media, New York.

29. Li, Y. and Yeh, Y. (2010). 'Increasing trust in mobile commerce through design aesthetics,' Computers in Human Behaviour, vol. 26, pages 673-684.

30. Liu, D. and Liou, C. (2011). 'Mobile commerce product recommendations based on hybrid multiple channels,' Electronic Commerce Research and Applications, vol. 10, pages 94-104.

31. Mahatanankoon, P. and Vila-Ruiz, J. (2007). 'Why won't consumers adopt mcommerce? An exploratory study,' Journal Internet Commerce, vol. 6, pages113-128.

32. McKenna, G. (2014). 'Vente-privee.com to launch wine flash sales in the UK,' Harpers Wine Spirit, vol. 15, pages 37-47.

33. Michela, P., Carlotta, M.C. and Andrea, C. (2012). 'Organizational change: Business process reengineering or outsourcing?,' Economic Science Series, vol. 21, pages 277293.

34. Moshkovich, H. (2013). 'Influence of previous experiences on the acceptance of mobile commerce: A pilot study,' Franklin Bussiness \& Law Journal, vol. 1, pages 5979.

35. Newman, R.B. (2011)." Legal and regulatory risks associated with the growth of mobile marketing," [Online], [Retrieved April 23, 2015], http://www.mobilecommercedaily.com/le gal-and-regulatory-risks-associated-withthe-growth-of-mobile-marketing. 
36. Nielsen, J. and Tahir, M. (2002) Homepage Usability, New Riders Publishing, USA.

37. Peng, J., Quan, J. and Zhang, S. (2013). 'Mobile phone customer retention strategies and Chinese e-commerce,' Electronic Commerce Research \& Applications, vol. 12, pages 321-327.

38. Picoto, W. (2011) An organizational perspective of mobile business value: The effects of technological, organizational and environmental factors. ISEG-School of Economics and Management of the Technical University of Lisbon, Lisbon.

39. Picoto, W.N., Belanger, F. and Palmados-Reis, A. (2013). 'M-business organizational benefits and value: A qualitative study,' Journal of Oganizational Computing and Electronic Commerce, vol. 23, pages 287-324.

40. Robbins, S.P., Judge, T.A., Millet, B. and Boyle, M. (2011). Organizational Behavior, sixth ed., Pearson Australia Pty Ltd, Australia.

41. Rogers, E.M. (1995). Diffusion of Innovations, fourth ed., The Free Press, New York.

42. Rogers, E.M. (2003). Diffusion of Innovations, fifth ed., The Free Press, New York.

43. Roos, G. (2013). Earn customer loyalty for retailers: Survey. eWeek, pages 8-18.

44. Rysavy, P. (2013). "Mobile commerce survey," Information Week, [Online], [Retrieved April 23, 2015], http://reports.informationweek.com/inde $\mathrm{x}$.

45. Schwalbe, K. (2014) Information Technology Project Management, seventh ed., Cengage Learning, USA.

46. Siwicki, B. (2013). "Consumers make $\$ 12.84$ billion in mobile payments in 2012," [Online], [Retrieved April 23, 2015], http://www.internetretailer.com/2013/01 /16/consumers-make-1284-billionmobile-payments-2012.
47. Sulistiyaningsih, M., Tambotoh, J.C. and RockyTanaamah, A.R. (2014). 'Technology acceptance model and online learning media: An empirical study of online learning application in a private Indonesian university,' Journal of Theoretical and Applied Information Technology, vol. 69, pages 136-143.

48. Swilley, E. (2012). 'Determinants of the adoption of a mobile commerce strategy: The perceived benefits to the firm,' $A M A$ Summer Education Conference, vol. 23, pages 342-342.

49. Teo, T.S.H. (2001). 'Demographic and motivation variables associated with Internet usage activities,' Internet Research, vol. 11, pages 125-137.

50. Tiwari, R. and Buse, S. (2007) The Mobile Commerce Prospects: A Strategic Analysis of Opportunities in the Banking Sector, Hamburg University Press, Germany.

51. Thompson, A.A., Strickland, A.J. and Gamble, J.E. (2010) Crafting and Executing Strategy: The Quest for Competitive Advantage: Concepts and cases, seventeenth ed., McGraw-Hill Companies Inc., USA.

52. Valacich, J. and Schneider, C. (2014) Information Systems Today: Managing in the Digital World, sixth ed., Pearson Education Inc., New Jersey.

53. Wei, J. and Ozok, A. (2005). 'Development of a web-based mobile airline ticketing model with usuability features,' Industrial Management \& Data Systems, vol. 5, pages 1261-1277.

54. Wei, T.T., Marthandan, G., Chong, A.Y.L, Ooi, K.B. and Arumugam, S. (2009). 'What drives Malaysian m-commerce adoption? An empirical analysis', Industrial Management \& Data Systems, vol.109, pages 370-388.

55. Woodward, K., (2011), "North America will be the top NFC market in five years," [Online], [Retrieved April 23, 2015], http://www.internetretailer.com/2011/04 
/21/north-america-will-be-top-nfcmarket-five-years.

56. Zwikael, 0. (2008). 'Top management involvement in project management:
Exclusive support practices for different project scenarios,' International Journal Managing Projects, vol. 1, pages 387-403. 